\title{
THE JOURNAL OF POLITICS
}

\section{Invites You to Join Its Ever Increasing Circle of Readers The February, 1971, issue will contain:}

Nonviolence, Violence and Reason by William R. Marty

Ambition and the Political Vocation: Congressional Challengers in American Politics by Jeff Fishel

The Closed Rule and the Paradox of Voting by John C. Blydenburgh

Issue Conflict and Consensus: $A$ Comparative Study of Democratic and Republican Delegates to the 1968 National Conventions by John W. Soule and James W. Clarke Malapportionment and Roll-Call Voting in Indiana, 1923-1963: A Computer Simulation by C. Richard Hofstetter

Economic Development, Representative Mechanisms, Administrative Professionalism and Public Policies: A Comparative Analysis of Within-State Distributions of Economic and Political Traits by Ira Sharkansky

Ideology and Politics: The Rechtsstaat Idea in West Germany by Glenn Schram

Socio-Economic Conditions and Party Politics in Japan: A Statistical Analysis of the 1969 General Election by Chao-Jin Lee

\section{RESEARCH NOTES}

Military Interpretation of Federal Constitutions: A Critique by R. D. Dikshit

Political Ambitions and the Prosecutorial Office by Richard L. Engstrom

\section{Published Quarterly by the SOUTHERN POLITICAL SCIENCE ASSOCIATION \\ Peabody Hall, University of Florida \\ Gainesville, Florida 32601 \\ Subscription Rates: $\$ 8.00$, U.S.A.; $\$ 8.60$, Foreign; $\$ 5.00$, Student}

\section{" GaDERNOS BRASILEIROS" \\ Editor: \\ Revista Bimestral}

Vicente Barretto

Julho-Agosto de 1970

ARTIGOS

Apontamentos para Discussao de um Modelo de Reconciliacao.

$O$ Novo Realismo e as Velhas Tolices..

A Sociedade Erotica no Mundo Moderno

(Moda) - de Narciso ao Detrito.

O Milenio dos Antagonismos.

Grisolli \& Alice - Divino \& Maravilhoso

Os 90 milhoes de Medicos

$O$ Desafio Educacional.

\section{CONTOS}

As Aventuras de Jorgom Klin.

Cacilda Griseldis

POESIAS

Poemas 1 e 2.

Fragmentos de "Mirador"

O Culto, $\mathbf{O}$ Medo.

Rede, Canoa e Cabine

\section{LIVROS}

O Ponto-de-Partida de uma Obra.

Padre Cicero, Mito e Realidade.

Homem Verde

Edyla Mangabeira Unger Andre Emiliano do Lago ... Olympio Monat

Assinaturas: Por um ano (6 numeros) CR $\$ 15,00$

Outros Paises: Numero avulso, US $\$ 2.00 ;$ Por um ano (6 numeros), US $\$ 11.00$

Endereco para assinaturas: Rua Prudente de Morais, 129, Ipanema-ZC-37-Rio de Janeiro, G.B., Brasil.

Luiz Alberto Bahia David Bronheim Angelo de Aquino Francois Duchene Teresa Barros ... Macksen Luiz Jacinto Sebastiao Rego de Almeida

Ronaldo Periassu Claudio Lacerda C. Ronald Jose Batista Jose Batista Virgilio da Costa 


\section{Social Fragmentation and Political Hostility}

An Austrian Case Study. G. Bingham Powell, Jr. The theory that cumulative group affiliations increase conflict and instability in politics is tested by an analysis of fragmentation in the Austrian community of Hallein.

$\$ 7.50$

\section{United States Policy Toward Latin America}

A Study in Domestic and International Politics. $R$. Harrison Wagner. Analyzes the major U.S. government decisions on economic policies made from the end of World War II to the beginnings of the Alliance for Progress.

$\$ 7.95$

\section{The Sokagakkai and Mass Society}

James $W$. White. Since World War II the Sokagakkai has become the third strongest political party in Japan. This study analyzes both its membership and ideology in terms of William Kornhauser's theory of mass society.

$\$ 12.95$

IN PAPERBack

The Structure of Freedom

With a New Preface (1970) вy the Author. Christian Bay. "Always stimulating, always enlightening."-Sociology and Social Research. Cloth, $\$ 10.00$; paper, $\$ 3.75$

Mass Media and

National Development

The Role of Information in the Developing Countries. Wilbur Schramm. "A sound basis for planning the mobilization of human resources."-The Annals.

Cloth, $\$ 8.50$; paper, $\$ 3.25$

\section{STANFORD UNIVERSITY PRESS}




\section{FORO INTERNACIONAL}

A Quarterly Journal Published by El Colegio de Mexico

Founder: Daniel Cosio Villegas

Editor: Roque Gonzalez Salazar

Assistant Editor: Maria Del Rosario Green

Issue Number 2, Volume XI (October-December, 1970) will be devoted to commemorating the

\section{ANNIVERSARY OF THE UNITED NATIONS}

The issue will include papers specially written for the Journal by: JORGE CASTANEDA

SIDNEY DELL.

JOHN DUGARD

TASLIM ELIAS

RICHARD FALK

WOLFGANG FRIEDMANN

ALFONSO GARCIA ROBLES

RICHARD GARDNER

ALAN JAMES

FERNANDO LABASTIDA

MANFRED LACHS

MYRES MCDOUGALL

EDUARDO JIMEI

EDWARD MCWHINNEY

STANLEY METZGER

A. H. ROBERTSON

JOSE MARIA RUDA

GEORG SCHWARZENBERGER

\section{DE ARECHAGA FESAR SEPULVEDA} GRIGORI TUNKIN

Price of the special issue: US $\$ 3.20$ Annual Subscription: US $\$ 6.00$

(Subscribers with subseriptions dated before July 31 will get this special issue without extra charge)

FORO INTERNACIONAL

El Colegio de México, Guanajuato 125, México 7, D.F.

Research

and

Publications

Library

Information

Service

Educational

Activities

For Information Munich Office - Mannhardtstrasse 6 and Subscriptions: 8 Munich 22, Germany

The results of Institute research are published in book and periodical form in seven languages: English, Russian, German, French, Spanish, Turkish and Arabic.

The Institute's 75,000-volume library of Soviet materials is widely used by visiting researchers from all parts of the world.

An information service is provided to answer questions about the USSR.

A university-accredited Russian language and Soviet area study program is conducted at the Institute, as well as a visiting professorship program.

$$
8 \text { Munich 22, Germany }
$$

\section{INSTITUTE FOR THE STUDY OF THE USSR}

An International Research and Study Center, Founded in 1950, with Headquarters in Munich, Germany. 


\section{THE SOUTHERN REVIEW JANUARY 1971}

A Now and Important Essay by

ERIC VOEGELIN

on Henry James's

The Turn of the Screw

with Three Related Essays

The Changing Pattern of Voegelin's Conception of Hislory and

Consciousness.

William C. Havard

Eric Voegelin's Anamnesis. Dante Germino

Melville and the Deformation of Being: From Typee to

Leviathan. James L. Babin

Subseribe Nowl Only $\$ 4.00$ a year (4 issues)

(Subscription rates will be increased after April 1)

Address:

The Business Manager, THE SOUTHERN REVIEW

Drawer D, University Station, Baton Rouge, Louisiana 70803

\section{INTERNATIONAL ORGANIZATION \\ announces a special issue for Autumn 1970 REGIONAL INTEGRATION}

\section{- Theory and Research -}

Leading scholars explore the theorefical and empirical aspects of the study of regional integration in the most comprehensive and up-to-date work in the field.

EDITORS

Leon N. Lindberg Stuart A. Scheingold CONTRIBUTORS

Hayward R. Alker Fred M. Hayward Ronald Inglehart Andrzej Korbonski Leon N. Lindberg Joseph S. Nye

Donald J. Puchala Stuart A. Scheingold Philippe C. Schmitter VOLUME 24 NUMBER 3

Individual copies of this issue will be available in paperback or cloth edition from Harvard University Press or as part of a subscription to Intemational Organization.

Subscription Rate: $\$ 7.50$ a year; $\$ 19.00$ three years WORLD PEACE FOUNDATION 40 Mount Vernon Street, Boston, Massachusetts 02108 


\section{POLITICAL SCIENCE REVIEW}

(Quarterly Journal of the Department of Political Science,

Vol. 9 University of Rajasthon, Jaipur, India)

\section{JANUARY-JUNE, 1970 SPECIAL GANDHI NUMBER}

Nos. $1 \& 2$

S. P. Varma

Orar Homage

Aloo I. Dastur

Salt Satyagraha.

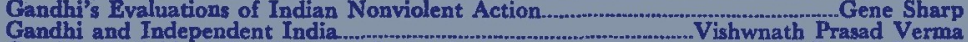

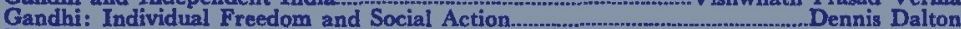

Ethical Basis of Gandhian Thought...................................................................... Usha Mehta

Gandhi and the West........... K. Kaul

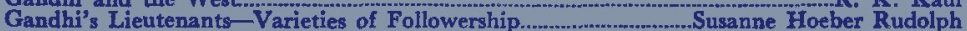

Gandhian Theory of Action and Radical Ideologies.................................... Yogendra Singh

Gandhi and the Concept of 'Aparigraha' .............................. Chandrasekhara Rao

The Place of Martin Luther King in the Negroes' Struggle for Equality...... H. S. Takulia

Negro Revolution and Nonviolent Action: Martin Luther King..................ulford Q. Sibley

NOTES AND MEMORANDA

Gandhiji and English.

P. S. Sundaram

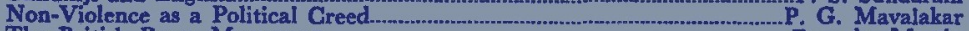

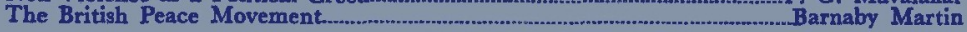

\section{Order from:}

Book Reviews, etc.

The Managing Edifor, THE POLITICAL SCIENCE REVIEW, University of Rajasthan, Jaipur (India)

Subscription Rates:

India: Rs. 16.00 , U.K.: Sh. $31 / .$, U.S.A.: \$5.00.

\section{ESTUDIOS INTERNACIONALES}

(Revista del Instifuto de Esfudios Infernacionales de la Universidad de Chile) Director: Jose CAyUELA

Consejo de Redaccion: Darcy Ribeiro, T. V. Sathyamurthy, Osvaldo Sunkol, Claudio Voliz

\begin{tabular}{lll}
\hline Ano IV & octubre-diciembre 1970 & Numero 15 \\
\hline
\end{tabular}

Sumario

Las Relaciones Internacionales Asiaticas: Perspectivas Contemporaneas

T. V. Sathyamurthy

Venexuela: Una Decada de Democracia Capitalista James Petras

El Presidente de los Estados Unidos y la Facultad para hacer la guerra...Julio Faundez B. Notas sabre los aspectos sociales y economicos de los "Regimenes

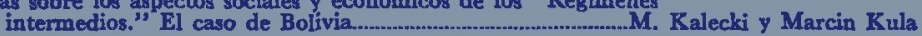

El Frente Nacional en Colombia. Gorman Rama

\section{Resenas de Libros}

Libros recibidos

Precios: Suscripcion anual en Chile, E108.00; America Latina, US\$10.00 fuera de America Latina, US\$13.00.

\section{ESTUDIOS INTERNACIONALES}

Departamento de suseripciones

Casilla 14187, Correo 21, Santiago de Chile 